\title{
Part II Quantitative study of the distribution of gastrin-like activity along the gut
}

In the study of the topographic distribution of gastrin-like activity in the normal human gastrointestinal tract, much attention has been paid to the stomach and far less to the rest of the gut.

Extracts of human gastric mucosa have been studied by several workers. Ammon and Lim (1923) extracted post-mortem specimens (21-63 hours after death) and found little or no activity, though histamine was also probably present in their extracts. Ivy and Oberhelman (1923-24) applied Keeton and Koch's method (1915) of extraction of gastric and duodenal mucosa obtained one hour to four days after death and found activity in all extracts, the gastric mucosa being approximately equipotent with hog antral mucosa and the duodenal mucosa about half of that. Uvnäs (1945) studied 24 post-mortem human stomachs (obtained 10-36 hours after death) using the extraction method of Munch-Petersen, Rönnow, and Uvnäs (1944), and reported considerable activity in 14 and slight activity in four extracts of the antral mucosa; extracts of the body mucosa and of the 'boundary zone' between the body and antral mucosa were all negative. Fifteen post-mortem specimens of duodenal mucosa were also extracted, and only slight activity found in three. Harper, Blair, and Reed (1962), using their own extraction procedures (Blair, Harper, Lake, Reed, and Scratcherd, 1961), also found activity in the antral mucosa obtained soon after death.

No published information is available for the gastrin-like activity in the rest of the normal gut.

The pancreas has attracted considerable attention since Zollinger and Ellison (1955) described two patients with pancreatic tumours associated with the syndrome which has since been named after them. Marked hypersecretion of hydrochloric acid from the stomach, with its sequel, was a prominent feature of the syndrome, and the causal relationship of the pancreatic tumours was substantiated when Gregory, Tracy, French, and Sircus (1960) demonstrated extractable grastin-like activity in one of them. Ample confirmation was obtained later (Grossman, Tracy, and Gregory, 1961; Code, Hallenbeck, and Summerskill, 1962; Hallenbeck, Code, and Kennedy, 1963). Hallenbeck, Code, and Mcllrath (1963), however, could find no activity in extracts of normal pancreatic tissue from man as well as from dog, hog, and monkey.

\section{MATERIALS AND METHODS}

Apparently normal tissues, confirmed histologically, were obtained at various distances along the gut from different patients at operation, and were extracted for gastrin-like activity, within 30 minutes of their resection, by the method of Grossman et al. (1961). The materials included: (a) the pancreas, gastric antrum, duodenum, and a short segment of the adjacent jejunum from one patient in whom Whipple's operation was carried out for a localized leiomyosarcoma in the second part of the duodenum (patient A); (b) two other pieces of pancreas from block dissection during gastrectomy for carcinoma of the stomach (patients B and C); (c) two lengths of terminal ileum from a patient with endometriosis involving the gut, and another patient with total colectomy for polyposis coli (patients D and E); and (d) two portions of sigmoid colon removed from two patients because of redundancy leading to partial volvulus (patients F and G).

The method used for the biological assay of gastrin-like activity in these extracts, together with evidence for reproducibility of the extraction procedure, have been described elsewhere (Lai, 1962, 1963), and are given in Part I.

\section{RESULTS}

The findings are shown in the accompanying table. It will be noted that $(a)$ the highest concentration of gastrin-like activity occurred in the antral mucosa; $(b)$ there is a clear gradient of concentration of activity down the gut, with its maximum in the antral mucosa; $(c)$ although the unit activity in the

\section{TABLE}

RESULTS SUMMARIZED

\begin{tabular}{|c|c|c|c|c|}
\hline Patient & Tissue & $\begin{array}{l}\text { Unit Activity } \\
\text { ( } \mu g . \text { standard } \\
\text { per } \mathrm{g} . \\
\text { tissue })\end{array}$ & $\begin{array}{l}\text { Approxi- } \\
\text { mate Ratio } \\
\text { of Unit } \\
\text { Activity }\end{array}$ & $\begin{array}{l}\text { Total Activity } \\
\text { ( } \mu \text { g. of standard } \\
\text { with fiducial } \\
\text { range } P=0.05 \text { ) }\end{array}$ \\
\hline $\begin{array}{l}\text { A, B, } \\
\text { and C } \\
\text { A } \\
\text { A } \\
\text { A } \\
\text { D }\end{array}$ & $\begin{array}{l}\text { Pancreas } \\
\text { (3 specimens) } \\
\text { Antral mucosa } \\
\text { Duodenal } \\
\text { mucosa } \\
\text { Jejunal mucosa } \\
\text { Ileal mucosa } \\
\text { (1) } \\
\text { Ileal } \\
\text { mucosa (2) } \\
\text { Colonic } \\
\text { mucosa (1) } \\
\text { Colonic } \\
\text { mucosa (2) }\end{array}$ & $\begin{array}{l}0 \\
46 \\
33 \cdot 5 \\
12 \\
3 \cdot 4 \\
4 \cdot 7 \\
\text { About } 0.5 \\
\text { About } 1 \cdot 5\end{array}$ & $\begin{array}{l}0 \\
13 \cdot 5 \\
10 \\
3 \cdot 5 \\
1 \\
1 \cdot 5\end{array}$ & $\begin{array}{l}0 \\
1,300(79-130 \%) \\
2,180(89-127 \%)\end{array}$ \\
\hline
\end{tabular}


duodenal mucosa was less than that in the antral mucosa, the total extractable activity was distinctly greater; and $(d)$ the normal pancreas persistently failed to yield any activity.

The histamine content of all these extracts has been estimated in the superfused guinea-pig ileum preparation (Adam et al., 1957) and found to be less than $50 \mathrm{ng} . / \mathrm{ml}$. of the extract. Not more than $1 \mathrm{ml}$. of any extract was used in each dose during the assay procedure.

\section{DISCUSSION}

In Edkins' (1906) original concept, the source of gastrin was limited to the gastric mucosa. However, the demonstration of gastrin-like activity extractable from the mucosa of the duodenum and upper jejunum confirmed the findings of previous workers and further substantiated the physiological evidence (Sircus, 1953) for the presence of an intestinal phase of gastric secretion. It may seem appropriate then to expand the definition to include the agent from the upper small intestinal mucosa which stimulated acid gastric secretion.

Since release of the hormonal agent from the antrum as well as the small intestine can be brought about by similar methods and inhibited by similar agents, it is tempting to suggest that the upper small intestine could play an important role in the physiological control of gastric secretion. This does not, however, necessarily mean that the active agents from the two sources are identical in structure, though their modes of release and action may be closely similar. Indeed, there are apparent discrepancies. Thus the hog duodenal mucosa yielded no activity when extracted by a method which was highly effective with hog antral mucosa (Gregory and Tracy, 1961); the reports by different authors on the activity of duodenal mucosal extracts from dog, cat, and hog, as tested in anaesthetized cats and conscious dogs, were not in agreement (Komarov, 1942; Uvnäs, 1943; Harper, 1946), and an extract of fresh hog duodenal mucosa made by the method of Grossman et al. (1961) and found very active in the rat was not active in a conscious $\operatorname{dog}$ (R. A. Gregory, personal communication). These observed discrepancies could be accounted for by one or more of the following possibilities: a difference in behaviour between the conscious and the anaesthetized animal, a real difference between gastrin of antral and duodenal origin, or species specificity in some cases.

The answer must await repetition of these tests using the purified agent from the duodenum, whether it be gastrin or a gastrin-like substance.

If it is assumed that the extractable gastrin-like activity in the duodenum is a reliable index of its activity under physiological conditions, then its possible significance in relation to the surgical treatment of duodenal ulcers may need consideration. However, little is known about the importance of the cholinergic mechanism or the conditions in the duodenum for the release of duodenal 'gastrin', and, with gastrectomy, the consequent diversion of the gastric chyme and loss of parietal cell mass would seem effective ways of minimizing release of, and response to, the hormone, irrespective of its amount in the duodenal mucosa. In any case, with current methods of gastric surgery for patients with duodenal ulcer, the rate of recurrent jejunal ulceration remains low despite preservation of the duodenum in all cases. The problem seems therefore more academic than practical at present, though final assessment cannot be made until further clinical and experimental evidence is available.

Elman and Hartmann (1931) found experimental evidence suggesting a role of the pancreas in the causation of peptic ulceration when they observed that diversion of the exocrine pancreatic secretion away from the duodenum almost invariably led to duodenal ulceration. Total pancreatectomy with similar deprivation of the alkaline pancreatic juice, however, rarely did so (Dragstedt, Clark, and Vermeulen, 1939). Based on these findings, Poth, Manhoff, and Deloach (1948) suspected that the islet tissues might produce an endocrine secretion causing peptic ulceration. The abundant gastrin-like activity extractable from Zollinger-Ellison tumours supports this idea in so far as the pathological pancreas is concerned. However, the persistent absence of gastrin-like activity in the normal pancreas, in confirmation of the findings of Hallenbeck et al. (1963), seems difficult to fit in with the postulate. Whether this is a quantitative or really a qualitative difference remains to be seen. Zollinger and McPherson (1958) and Summerskill (1959) had reported instances where the ZollingerEllison syndrome occurred in patients in whom the pancreas showed hyperplasia of the islets (most probably the alpha cells) without any detectable neoplasms. Furthermore, Summerskill, Code, Hallenbeck, and Priestley (1961) noted that histologically normal pancreas could yield activity when the rest of that same gland was studded with multiple adenomata which yielded much higher activity when extracted and tested in the same manner. These findings could be interpreted as either that the amount of gastrin-like substance produced (if any) by the normal number of islet cells could not be detected by the methods of extraction and assay used, or that the normal pancreas produced no gastrin but the factors which (probably) led to hyperplasia and neoplasia in the islets also conferred 
upon them the ability to produce a gastrin-like substance.

Two further points are worthy of note. (1) There has been, so far, no positive histological identification of the cell type(s) in these Zollinger-Ellison tumours (Zollinger and Craig, 1960; Chvojka, 1960), nor real proof that they did arise from islet cells, apart from morphological resemblances to the alpha cells in some of the cases.

(2) Morphologically, no single type of cell has been found common to all the known sites of formation of gastrin (or gastrin-like substances) in man, viz., the antral and duodenal mucosa and ZollingerEllison tumours. However, the pancreas shares a common embryological origin with the gastrointestinal mucosa in the endodermal lining of the gut (Ham and Leeson, 1961, and others). If one assumes that gastrin is produced by only one type of cell, and that all gastrin-like substances are in fact gastrin, then it may be that cells from this common embryological origin retain their potential ability to produce gastrin irrespective of the final differentiation. The solution to this problem most probably lies in a reliable method of identifying the 'gastrin cell'. The immunological approach with the fluorescent antibody technique, as suggested by Monaco, Lythgoe, and Waddell (1961), may prove valuable.

Little interpretation can be made of the presence of gastrin-like activity in the lower gut. It is perhaps appropriate to re-emphasize that the antral and upper small intestinal mucosa are, to date, the only sites where the existence of gastrin (or gastrin-like substances) is supported by physiological evidence. All other active fractions are extraction products. This does not exclude their existence, but their physiological role has not been established. Their positive indentification on biochemical grounds in future may add more meaning to the present findings.

\section{SUMMARY}

Gastrin-like activity in human tissues was assayed using the anaesthetized rat. It was present in the highest concentration in the antral mucosa and decreased along the gut. No activity could be detected in normal pancreatic tissue. The significance of these findings in relation to the Zollinger-Ellison syndrome and the physiological role of the duodenum is discussed.

\section{REFERENCES}

Adam, H. M., Hardwick, D. C., and Spencer, K. E. V. (1957). A method of estimating histamine in plasma. Brit. J. Pharmacol., 12, 397-405.

Ammon, S. E., and Lim, R. K. S. (1923). The 'gastrin' content of the human pyloric mucous membrane, Brit. J exp. Path, 4, 27-29.

Blair, E. L., Harper, A. A., Lake, H. J., Reed, J. D., and Scratcherd T. (1961). A simple method of preparing gastrin. J. Physiol. (Lond.), 156, 11-12P.

Chvojka, V. E. (1960). Islet-cell tumors and peptic ulcers: case report of the Zollinger-Ellison syndrome. Ann. intern. med., 53 1180-1195.
Code, C. F., Hallenbeck, G. A., and Summerskill, W. H. J. (1962). Extraction of a gastric secretagogue from primary and metastatic islet cell tumors in $\mathbf{3}$ cases of Zollinger-Ellison syndrome. J. surg. Res., 2, 136-140.

Dragstedt, L. R., Clark, D. E., and Vermeulen, C. (1939). The significance of lipocaic in surgery. Ann. Surg., 110, 907-915.

Edkins, J. S. (1906). The chemical mechanism of gastric secretion. J. Physiol. (Lond.), 34, 133-144.

Elman, R., and Hartmann, A. F. (1931). Spontaneous peptic ulcers of duodenum after continued loss of total pancreatic juice. Arch. Surg., 23, 1030-1040.

Gregory, R. A., and Tracy, H. J. (1961). The preparation and properties of gastrin. J. Physiol. (Lond.), 156, 523-543.

,-- , French, J. M., and Sircus, W. (1960). Extraction of a gastrin-like substance from a pancreatic tumour in a case of Zollinger-Ellison syndrome. Lancet, 1, 1045-1048.

Grossman, M. I., Tracy, H. J., and Gregory, R. A. (1961). ZollingerEllison syndrome in a Bantu woman, with isolation of a gastrinlike substance from the primary and secondary tumors. II. Extraction of gastrin-like activity from tumors. Gastroenterology, 41, 87-91.

Hallenbeck, G. A., Code, C. F., and Kennedy, J. C. (1963). Effects of extracts of primary and metastatic pancreatic islet cell tumors on gastric secretion. Ibid., 44, 631-636.

,-- , and McIlrath, D. C. (1963). Absence of demonstrable gastric secretagogue in normal pancreatic tissue. Ibid., 44, 627-630.

Ham, A. W., and Leeson, T. S. (1961). Histology, 4th ed., p. 633. Pitman, London.

Harper, A. A. (1946). The effect of extracts of gastric and intestinal mucosa on the secretion of $\mathrm{HCl}$ by the cat's stomach. $J$. Physiol., 105, 3P.

Sci., 22nd Congress, Leyden, vol. 1, p. 334-337.

Ivy, A. C., and Oberhelman, H. A. (1923-24). The presence of 'gastrin' in human postmortem pyloric and duodenal mucosa. Amer. $J$. Physiol., 68, 451-453.

Keeton, R. W., and Koch, F. C. (1915). The distribution of gastrin in the body. Ibid., 37, 481-504.

Komarov, S. A. (1942). Studies on gastrin. II. Physiological properties of the specific gastric secretagogue of the pyloric mucous membrane. Rev. canad. Biol., 1, 377-401.

Lai, K. S. (1962). A method of biological assay of gastrin and its application to the study of human tissues. Ph.D. Thesis, University of Edinburgh.

- (1963). Surgical physiology of the gastrointestinal tract. Symp. roy. Coll. Surg. Edinb., p. 85.

Monaco, A. P., Lythgoe, J. P., and Waddell, W. R. (1961). Immunological study in the Zollinger-Ellison syndrome. Lancet, 2, 1016-1017.

Munch-Petersen, J., Rönnow, G., and Uvnäs, B. (1944). Further studies on the gastric secretory excitant from the pyloric mucous. Acta physiol. scand., 7, 289-302.

Poth, E. J. Manhoff, L. J. Jr., and Deloach, A. W. (1948). The relation of pancreatic secretion to peptic ulcer formation: effect of pancreatectomy, ligation of pancreatic ducts, and diabetes on the production of histamine-induced ulcers in the dog. Surgery, 24, 62-69.

Sircus, W. (1953). The intestinal phase of gastric secretion. Quart. J. exp. Physiol., 38, 91-100.

Summerskill, W. H. J. (1959). Malabsorption and jejunal ulceration due to gastric hypersecretion with pancreatic islet-cell hyperplasia. Lancet, 1, 120-123.

—, Code, C. F., Hallenbeck, G. A., and Priestley, J. T. (1961). Intractable peptic ulcer in hereditary endocrine-ulcer disease: 'gastrin' content of endocrine tissues. Proc. Mayo Clin., 36, 611-617.

Uvnäs, B. (1943). Gastric secretory excitant from the pyloric mucosa. Acta physiol. scand., 6, 97-103.

- (1945). Further attempts to isolate a gastric secretory excitant from the pyloric mucosa of pigs. Ibid., 9, 296-305.

Zollinger, R. M., and Craig, T. V. (1960). Ulcerogenic tumors of the pancreas. Amer. J. Surg., 99, 424-432.

jejunum associated with islet cell tumors of the pancreas. Ann. Surg., 142, 709-728.

- and McPherson, R. C. (1958). Ulcerogenic tumors of the pancreas. Amer. J. Surg., 95, 359-365. 